\title{
Respon Pertumbuhan Bibit Kelapa Sawit (Elaeis jaquinensis) Terhadap Pemupukan Phospor Dan Dolomit
}

\section{Respons of Growth Seedling Kelapa Sawit (Elaeis jaquinensis) to Phospor Fertilizerand Dolomit}

\author{
Purwati \\ Tenaga Pendidik Program Studi Agroteknologi, Fakultas Pertanian, Universitas Widya Gama Mahakam \\ Jl. KH. Wahid Hasyim, Sempaja, Samarinda, Kalimantan Timur, Indonesia. \\ email : purwatibaik@yahoo.co.id
}

Diterima : 3 April 2012 Disetujui : 30 April 2012

\begin{abstract}
ABSRACT
The research aimed to identify the growing of seedling Elaeis jaquinensis on Phospor fertilizer and Dolomit Application, as well as its interaction, and to find the proper concentration of Phospor fertilizer for seedling Elaeis jaquinensis. This research lasted for four months, from Oktober2010to Januari 2011, at the Village of Sempaja Sub District of Samarinda. The research was designed in Completely Randomized Block Design with Factorial $3 \times 4$ and three replications. The first factor comporised of 3 levels of Phospor dosage (1,5, 2,0 and 2,5 g SP-36/polybag and the second factor was dolomit dosage $(0,10,15$ and $20 \mathrm{~g}$ dolomit/polybag. The results showed that: (1) significant responses the phosphor fertilizer on the parameters of number of leaf at the stage of 90 old days and diameter of stemat the stage of 60 old days; (2) significant responses on the Dolomiton the parameters of diameter of stemat the stage of 30 and 60 old days; (3) significant responses the interaction between phospor fertilizer and Dolomit application on the parameter of number of leaf at the stage of 60 old days.
\end{abstract}

Keywords : Kelapa Sawit(Elaeis jaquinensis), phospor fertilizer, dolomite

\section{PENDAHULUAN}

Kelapa sawit (Elaeis guineensis Jacq) merupakan salah satu komoditas penting dalam perekonomian Indonesia. Luas kebun terus berkembang dan tidak hanya monopoli kebun besar negara atau perkebunan besar swasta, tetapi perkebunan kelapa sawit rakyat sudah berkembang dengan pesat pula (Risza, 1994).

Kalimantan Timur merupakan salah satu daerah yang mempunyai potensi pengembangan perkebunan kelapa sawit yang ideal. Berdasarkan data Dinas Perkebunan (Disbun) Kaltim, diperkirakan luas areal perkebunan kelapa sawit meningkat dari 171.581 hektar pada tahun 2004 menjadi 530.555 hektar pada tahun 2009, dengan pertumbuhan rata-rata $41.84 \%$ pertahun. Sedangkan, mengenai produksi yang telah meningkat dari 957.058 ton pada tahun 2004 menjadi 2,29 juta ton pada tahun 2009 atau terdapat peningkatan produksi sebesar $28,03 \%$. Untuk mencapai produksi yang mantap diperlukan upaya terpadu antara teknik budidaya dan pengolahan sumberdaya lahan yang tepat. Berkenaan dengan hal tersebut masalah yang dihadapi saat ini adalah selain tingkat kesuburan tanah yang rendah, masih rendahnya teknologi budidaya yang dimiliki. Penyedian bibit yang berkualitas baik merupakan faktor yang menentukan keberhasilan dalam produksi buah sawit.

Salah satu faktor yang harus diperhatikan dalam usaha pengembangan tanaman kelapa sawit adalah tersedianya bibit berkualitas tinggi dalam jumlah yang cukup. Di samping pemilihan pupuk SP-36, penggunaan kapur dolomit juga sangat penting. Pemupukan adalah usaha menambah unsur hara yang dibutuhkan oleh tanaman.

Menurut Suwardjo dkk (1995) dan Kahar (1995)bahwa pengembangan tanaman hortikultura di Kalimantan Timur untuk tanah yang didominasi jenis Ultisol, tingkat kesuburan tanahnya rendah dan bersifat masam. Tanah-tanah tersebut memiliki sifat yang menyebabkan pertumbuhan tanaman mengalami defisiensi $\mathrm{P}$, Keracunan $\mathrm{Al}$.

Menurut Karama dan Abdurrahman (1993)salah satu langkah dalam pendayagunaan lahan untuk produksi tanaman pangan dan hortikultura adalah memperbaiki sifat masam tanah tersebut. Tindakan memperbaiki sifat tanah ini disebut ameliorasi. Ameliorasi dimaksudkan untuk memperbaiki sifat-sifat fisik serta sekaligus juga memperbaiki sifat-sifat biologi. Bahan ameliorasi yang biasa digunakan adalah kapur atau bahan organik.

Ditambahkan (Adiningsih,1996) bahwa upaya pertama yang harus dilakukan adalah peningkatan kesuburan tanah antara lain dengan meningkatkan $\mathrm{pH}$ tanah, kandungan bahan organik dan meningkatkan hara khususnya fospat. Pemupukan dengan penambahan unsur fospat dan pemberian kapur diharapkan dapat memberikan pangaruh baik bagi pertumbuhan dan perkembangan tanaman.

Kapur yang diharapkan dapat berfungsi membenahi sifat KTK dan fisik tanah terutama kemasaman tanah, selanjutnya berfungsi juga menunjang ketersediaan unsur P. Dimana sifat kekurangan unsur $\mathrm{P}$ dan kemasaman tanah 
merupakan masalah pokok yang dihadapi bagi pemanfaatan lahan untuk usahatani secara umum di Kalimantan Timur dengan jenis tanah utamanya adalah Podsolik Merah Kuning (Ultisol). Meningkatnya kesuburan fisik dan kimia tanah yang tercipta melalui pengapuran dan penambangan unsur hara yang cukup akan meningkatkan produktivitas lahan dan pada akhirnya akan meningkatkan produksi tanaman yang dibudidayakan.

Menurut Lingga dan Marsono (2003), Setelah tanah pada kondisi yang baik maka pupuk merupakan kunci dari kesuburan tanah karena berisi satu atau lebih unsur untuk menggantikan unsur yang habis terserap tanaman. Jadi, memupuk berarti menambahkan unsur hara ke dalam tanah atau langsung pada tanaman melalui pupuk daun. Dari sekian banyak unsur hara yang tergolong makro, unsur fosfor $(\mathrm{P})$ merupakan salah satu yang sangat esensial dibutuhkan tanaman. Unsur fosfor (P) bagi tanaman berguna untuk merangsang

\section{BAHAN DAN METODE}

Penelitian ini dilaksanakan di Kelurahan Sempaja Kecamatan Samarinda Utara, Kota Samarinda. Penelitian berlangsung pada bulan bulan Oktober 2010 - Januari 2011. Penelitian dirancangRancangan Acak Kelompok yang terdiri atas dua faktor dengan tiga kali ulangan. Faktor pertama adalah dosis phospor terdiri atas 3 taraf $\mathrm{P}$ yaitu: $\mathrm{p}_{1}: 1,5 \mathrm{~g}$ SP-36/polybag, $\mathrm{p}_{2}: 2,0 \mathrm{~g}$ SP36/polybag, $\mathrm{p}_{3}: 2,5 \mathrm{~g}$ SP-36/polybag dan faktor kedua adalah dosis dolomit yang terdiri atas 4 taraf D yaitu : $\mathrm{d}_{0:} 0 \mathrm{~g}$ dolomit/polybag(kontrol), $\mathrm{d}_{1: 10 \mathrm{~g}}$ dolomit/polybag, $\mathrm{d}_{2:} 15 \mathrm{~g}$ dolomit/polybag, $\mathrm{d}_{3:} 20 \mathrm{~g}$ dolomit/polybag. Bahan yang digunakan dalam penelitian ini adalah bibit kelapa sawit umur 2 bulan, pupuk SP-36, Dolomit, topsoil, polybag, Dithane M 45, Furadan 3G. Kegiatan penelitian meliputi : (1) persiapan tempat penelitian (2) persiapan media tanam (3) pemberian kapur dolomit(4) penanaman (5)pemberian pupuk SP-36 (6) pemeliharaan tanaman. Peubah yang diamati adalah : (1) Pertambahan tinggi tanaman $(\mathrm{cm})$, pengukuran tinggi tanaman dilakukan pada saat tanaman berumur 30, 60 dan 90 hst.Pengukuran dilakukan mulai permukaan media dalam polibag

\section{HASIL DAN PEMBAHASAN}

Hasil sidik ragam menunjukkan bahwaperlakukan pupuk phosphor (p) memberikan pengaruh tidak nyata terhadap ratarata pertambahantinggi tanaman, pertambahan jumlah daun umur 30 dan 60 hari setelah tanam (hst),pertambahan diameter batang umur 30 dan 90 hst dan panjang pelepah daun namun memberikan pengaruh nyata terhadap rata-rata pertambahan jumlah daun umur 90 hstdan sangat nyata terhadap rata-rata pertambahan diameter pertumbuhan akar, khususnya akar benih dan tanaman muda. Selain itu, fosfor berfungsi sebagai bahan mentah untuk pembentukan sejumlah protein tertentu, membantu asimilasi dan pernapasan, serta mempercepat pembungaan, pemasakan biji dan buah. Pada tanah yang kekurangan fosfor, tanaman akan menampakkan gejala yaitu; warna daun seluruhnya berubah kelewat tua dan sering tampak mengkilap kemerahan. Tepi daun, cabang dan batang terdapat warna merah ungu yang lambat laun berubah menjadi kuning. Kalau tanamannya berbuah, buahnya kecil, tampak jelek, dan lekas matang. Berdasarkan uraian di atas maka perlu di lakukan penelitian mengenai respon bibit kelapa sawit terhadap pemberian pupuk phospor dan dolomit. Tujuan penelitian adalah untuk mengetahui pengaruhpupuk phospor dan dolomit terhadap pertumbuhan bibit kelapa sawit (Elaeis jaquinensis).

yang telah ditancapkan kayu kecil sebagai patokan awal titik tumbuh sampai pada helai daun tertinggi pada tanaman dengan menggunakan meteran. (2) Pertambahan jumlah daun (helai), penghitungan jumlah daun dilakukan pada saat tanaman berumur 30, 60 dan 90 hst,dengan menghitung jumlah daun yang tumbuh dan membuka sempurna. (3) Pertambahan diameter batang $(\mathrm{cm})$, Diameter pangkal batang yang dibentuk oleh pelepah daun diukur pada bagian batang terbesar pada saat tanaman berumur 30, 60 dan 90 hst.Pengukuran dilakukan dengan menggunakan jangka sorong. (4) Panjang pelepah daun (cm),panjangpelepah diukur dengan menggunakan penggaris, pengukuran dilakukan dengan cara mengukur panjang pelepah dari pangkal pelepah sampai ujung pelepah,pengukuran dilakukan pada saat tanaman berumur 30, 60 dan 90 hst.Data yang diperoleh dianalisis dengan menggunakan sidik ragam dan jika terdapat perbedaan yang nyata maka untuk membandingkan dua rata-rata perlakuan akan dilanjutkan dengan Uji Beda Nyata Terkecil (BNT) pada taraf 5\%. Dilakukan uji ortogonal polinomial untuk mengetahui hubungan antara pupuk phospor dan dolomit.

batang umur 60 hst pada perlakuan $\mathrm{p}_{3}(2,5 \mathrm{~g}$ SP36/polybag).

Perlakuan pupuk phospor memberikan pengaruh tidak nyata, diduga karena media tanam (top soil) dapat menyediakan unsur hara, air dan udara untuk mendukung pertumbuhan tanaman. Selain itu pupuk yang diberikan tidak dalam keadaan tersedia bagi tanaman sehingga belum dapat mendukung pertumbuhan tanaman. Untuk dapat tumbuh dengan baik tanaman tidak hanya 
membutuhkan hara yang cukup seimbang, tetapi juga memerlukan lingkungan fisik tanah yang cocok supaya akar tanaman dapat berkembang dengan bebas, proses-proses fisiologi bagian tanaman yang berada di dalam tanah dapat berlangsung dengan baik.

\section{Respon Bibit Kelapa Sawit terhadap Pemberian Pupuk Phospor}

Tabel 1. Rata-Rata Pertambahan Jumlah Daun (helai) pada Perlakuan Pupuk Phospor

\begin{tabular}{cccc}
\hline \multirow{2}{*}{ Pupuk Phospor } & \multicolumn{3}{c}{ Jumlah Daun (helai) } \\
\cline { 2 - 4 } & $30 \mathrm{hst}$ & $60 \mathrm{hst}$ & $90 \mathrm{hst}$ \\
\hline $\mathrm{p}_{1}$ & 2,33 & 2,83 & $3,67^{\mathrm{b}}$ \\
$\mathrm{p}_{2}$ & 2,17 & 2,75 & $3,67^{\mathrm{b}}$ \\
$\mathrm{p}_{3}$ & 2,00 & 2,67 & $3,68^{\mathrm{a}}$ \\
\hline
\end{tabular}

Keterangan : Angka-angka yang diikuti huruf yang sama menunjukkan tidak berbeda nyata berdasarkan uji BNT pada taraf $\alpha=5 \%$

Tabel 2. Rata-Rata Pertambahan Diameter Batang $(\mathrm{cm})$ pada Perlakuan Pupuk Phospor

\begin{tabular}{cccc}
\hline \multirow{2}{*}{ Pupuk Phospor } & \multicolumn{3}{c}{ Diameter Batang $(\mathrm{cm})$} \\
\cline { 2 - 4 } & $30 \mathrm{hst}$ & $60 \mathrm{hst}$ & $90 \mathrm{hst}$ \\
\hline $\mathrm{p}_{1}$ & 0,20 & $0,48^{\mathrm{b}}$ & 0,69 \\
$\mathrm{p}_{2}$ & 0,30 & $0,53^{\mathrm{b}}$ & 0,82 \\
$\mathrm{p}_{3}$ & 0,35 & $0,63^{\mathrm{a}}$ & 0,92 \\
\hline
\end{tabular}

Keterangan : Angka-angka yang diikuti huruf yang sama menunjukkan tidak berbeda nyata berdasarkan uji BNT pada taraf $\alpha=5 \%$

Menurut Harjadi (1993) bahwa kesuburan tanah secara tidak langsung berhubungan dengan komposisi kimia dari mineral-mineral anorganik primer, sedangkan faktor yang paling penting adalah tingkatan bentuk hara yang tersedia bagi tanaman. Tingkatan tersebut tergantung pada banyak faktor di antaranya kelarutan zat hara, $\mathrm{pH}$ tanah, kapasitas pertukaran kation, tekstur tanah, dan jumlah bahan organik yang ada.

Menurut Hakim dkk (1986) akar mempunyai peranan yang cukup besar dalam memperbaiki sifat fisik tanah, memperbaiki drainase dan aerasi tanah, serta sebagai penjaga keseimbangan unsur hara dalam larutan melalui serapan dan pelepasan asam asam organik sebagai pelarut.

Perlakuan pupuk phospor memberikan pengaruh yang nyata dan sangat nyata terhadap rata-rata pertambahan jumlah daun umur $90 \mathrm{hst}$ dan rata-rata pertambahan diameter batang umur 60 hst, diduga karenatelah terpenuhinya kebutuhan unsur hara yang diperlukan tanaman termasuk unsur $\mathrm{P}$ yang telah diberikan dalam bentuk pupuk SP-36. Sebagaimana dijelaskan dalam hukum minimum Liebig bahwa pertumbuhan tanaman akan optimal jika semua unsur hara yang diperlukan tersedia, sedangkan ketersediaan unsur secara keseluruhan dan optimum selanjutnya ditentukan oleh salah satu unsur yang keberadaannya minimum atau terbatas.Rata-rata pertambahan jumlah daun terbaik pada $\mathrm{p}_{3}$ dengan jumlah daun 3,68 helai. Sedangkan rata-rata pertambahan diameter terbaik pada $\mathrm{p}_{3}$ dengan diameter batang $0,63 \mathrm{~cm}$.

Hal yang sama juga di ungkapkan oleh Mitscherlich (1909) dalam Leiwakabesy (1989) bahwa apabila suatu tanaman ditanam dalam keadaan lingkungan yang baik serta semua unsur hara cukup tersedia kecuali satu unsur hara misalnya $\mathrm{P}$ yang terdapat dalam keadaan rendah maka pertumbuhan tanaman tersebut sebanding dengan jumlah unsur hara tersebut yang ditambahkan ke dalam tanah.

Terbatasnya unsur $\mathrm{P}$ pada tanah percobaan adalah memang merupakan salah satu ciri jenis tanah setempat, seperti dijelasankan Suwardjo et al. (1995) bahwa kandungan hara pada tanah Podsolik Merah Kuning (Ultisol) umumnya rendah. Kondisi ini diperburuk oleh kemasaman tanah, pada kondisi masam, kebanyakan unsur hara di tanah tidak atau kurang tersedia bagi tanaman. Selain dapat meracuni tanaman, kandungan Aluminium yang tinggi dapat pula mengendapkan anion-anion yang dibutuhkan tanaman terutama unsur fosfat, sehingga unsur fosfat tidak tersedia bagi tanaman.

Fitter dan Hay (1998) menjelaskan bahwa proporsi fosfat tanaman yang berada dalam bentuk anorganik bertambah dengan meningkatnya suplai $\mathrm{P}$, dan akibatnya total kandungan fosfat tanaman meningkat. Tetapi pengalokasian $\mathrm{P}$ dalam tanaman cukup kompleks. Akar dan pucuk berkompetisi secara efektif terhadap hara, yang bertingkah laku sebagai dua organisme simbiotik dengan produksi hasil fotosintesis oleh pucuk dan pengangkutannya ke akar menentukan kemampuan akar untuk memperoleh hara; suplai hara ke pucuk mengontrol laju photosintesis, dan sebaliknnya. Dengan demikian terdapat mekanisme timbal balik yang seimbang. 
Kemampuan tanam sawit menyerap unsur $\mathrm{P}$ yang diberikan juga tidak terlepas dari peran ketersediaan unsur hara lain yang memiliki hubungan positip dalam hal saling mendukung proses penyerapan hara secara keseluruhan. Seperti diijelaskan Nasution (1990) bahwa didalam tanah yang ideal bagi bercocok tanam kadar masing-masing unsur hara yang dibutuhkan tanaman dalam tanah harus berimbang.

Menurut Lingga dan Marsono (2003) tercukupinya jumlah unsur hara lain dapat meningkatkan penyerapan phosphor. Sebagai contoh, Amonium yang berasal dari nitrogen dapat meningkatkan penyerapan phosphor. Dari hasil analisis laboratorium. Terhadap tanah dari lokasi percobaan dapat diketahui bahwa sesungguhnya ketersediaan unsur lain seperti unsur $\mathrm{N}, \mathrm{K}$ dan bahan organik (C) memang jumlahnya cukup.

Unsur phosphor merupakan unsur terpenting kedua setelah nitrogen. Phosphor terdapat dalam asam nukleat dan didalam berbagai molekul yang berperan mengangkut energi, phosphor $(\mathrm{P})$ bagi tanaman berguna untuk merangsang pertumbuhan akar, khususnya akar tanaman muda. Selain itu phosphor berfungsi sebagai bahan mentah untuk pembentukan sejumlah protein tertentu; membantu asimilasi dan pernapasan.

Menurut Lingga dan Marsono (2003) ketersediaan phosphor dalam tanah ditentukan oleh banyak faktor, tetapi yang paling penting adalah $\mathrm{pH}$ tanah. Pertumbuhan tanaman sebagai hasil dari suplai unsur hara termasuk unsur $P$ tidak lepas dari peranan $\mathrm{pH}$ tanah yang optimum bagi proses penyeyapan unsur $\mathrm{P}$ oleh tanaman.

\section{Respon Bibit Kelapa Sawit terhadap \\ Pemberian Dolomit}

Tabel 3. Rata-Rata Pertambahan Diameter Batang (cm) pada Perlakuan Dolomit

\begin{tabular}{cccc}
\hline \multirow{2}{*}{ Dolomit } & \multicolumn{3}{c}{ Diameter Batang $(\mathrm{cm})$} \\
\cline { 2 - 4 } & $30 \mathrm{hst}$ & $60 \mathrm{hst}$ & $90 \mathrm{hst}$ \\
\hline $\mathrm{d}_{0}$ & $0,28^{\mathrm{b}}$ & $0,47^{\mathrm{bc}}$ & 0,70 \\
$\mathrm{~d}_{1}$ & $0,22^{\mathrm{c}}$ & $0,44^{\mathrm{c}}$ & 0,98 \\
$\mathrm{~d}_{2}$ & $0,36^{\mathrm{a}}$ & $0,69^{\mathrm{a}}$ & 0,86 \\
$\mathrm{~d}_{3}$ & $0,28^{\mathrm{b}}$ & $0,57^{\mathrm{b}}$ & 0 \\
\hline
\end{tabular}

Keterangan : Angka-angka yang diikuti huruf yang sama menunjukkan tidak berbeda nyata berdasarkan uji BNT pada taraf $\alpha=5 \%$

Hasil sidik ragam menunjukkan bahwa perlakukan dolomit (d) memberikan pengaruh tidak nyata terhadap rata-rata pertambahantinggi tanaman, pertambahan jumlah daun, pertambahan diameter batang umur 30 dan panjang pelepah daun namun menunjukkan pengaruh yang nyata dan sangat nyata terhadap rata-rata pertambahan diameter batang umur 30 dan 60 hst pada perlakuan $\mathrm{d}_{2}(15 \mathrm{~g}$ dolomit/polybag). Hal ini diduga karena telah terpenuhinya kebutuhan unsur hara yang diperlukan tanaman terutama unsur nitrogen melalui pemberian pupuk SP- 36 dan urea. Menurut Sarief (1986) pemberian pupuk akan lebih efektif bila dilakukan pada tanah yang mengalami defisiensi unsur hara, sehingga dapat dimanfaatkan bagi pertumbuhan tanaman.

Menurut Sutedjo (1999) bahwa nitrogen merupakan unsur hara utama bagi pertumbuhan tanaman terutama dalam pembentukan daun, batang dan akar, diantara fungsi utamanya adalah untuk meningkatkan pertumbuhan tanaman dan menyehatkan pertumbuhan daun.

Menurut Sastrosayono (2003) bahwa kebutuhan unsur hara bagi tanaman kelapa sawit pada setiap fase pertumbuhannya berbeda beda. Penambahan dosis pupuk ada batasnya, di atas batas dosis tersebut akan berpengaruh negatif.

Dari hasil tersebut diduga pada tahap pertumbuhan awal pembibitan, kebutuhan tanaman akan pupuk sangat besar. Hal ini berkaitan dengan ketersediaan hara yang rendah mengindikasikan bahwa tanah yang digunakan untuk media tanam mempunyai kapasitas tukar kation (KTK) rendah. Pupuk yang diberikan maupun yang berada pada media tanam tidak mampu diserap oleh tanaman karena kondisi $\mathrm{pH}$ yang rendah.

Hal ini dikarenakan pemberian dolomit tersebut tidak dapat memperbaiki sifat kimia tanah terutama KB, KTK dan $\mathrm{pH}$ tanah. Rendahnya KB, KTK dan pH tanah menyebabkan unsur hara tidak mampu diserap oleh tanaman, karena pada kondisi $\mathrm{KB}$, KTK dan $\mathrm{pH}$ rendah, unsur $\mathrm{P}$ yang ada didalam tanah terjerap oleh kation $\mathrm{Al}$ dan Fe pada permukaan liat.

Menurut Winarso (2005) bahwa indikasi tingkat kesuburan tanah dapat dilihat dari besarnya persentase kejenuhan basa. Makin besar nilai $\mathrm{KB}$ suatu tanah maka unsur hara esensiil (P, $\mathrm{K}, \mathrm{Ca}$, dan $\mathrm{Mg}$ ) lebih tersedia dan mudah dimanfaatkan tanaman. Sedangkan nilai KTK tanah mempunyai arti yang sangat penting dalam hubungannya dengan suplai unsur hara, dan juga mempunyai pengaruh terhadap daya sangga tanah. Makin tinggi KTK dan KB makin tinggi kemampuan tanah dalam menyimpan dan melepaskan kation serta makin kuat daya sangganya. 


\section{Respon Bibit Kelapa Sawit terhadap Interaksi Pupuk Phospor dan Dolomit}

Tabel 4. Rata-Rata Pertambahan Jumlah Daun (helai) pada Perlakuan Interaksi Pupuk Phospor dan Dolomit

\begin{tabular}{cccc}
\hline \multirow{2}{*}{ Dolomit } & \multicolumn{3}{c}{ Jumlah Daun (helai) } \\
\cline { 2 - 4 } & 30 hst & 60 hst & 90 hst \\
\hline $\mathrm{p}_{1} \mathrm{~d}_{0}$ & 3,00 & $3,67^{\mathrm{a}}$ & 4,33 \\
$\mathrm{p}_{1} \mathrm{~d}_{1}$ & 2,00 & $2,33^{\mathrm{b}}$ & 3,67 \\
$\mathrm{p}_{1} \mathrm{~d}_{2}$ & 2,33 & $3,00^{\mathrm{ab}}$ & 3,33 \\
$\mathrm{p}_{1} \mathrm{~d}_{3}$ & 2,00 & $2,33^{\mathrm{b}}$ & 3,33 \\
$\mathrm{p}_{2} \mathrm{~d}_{0}$ & 2,33 & $3,00^{\mathrm{ab}}$ & 4,00 \\
$\mathrm{p}_{2} \mathrm{~d}_{1}$ & 2,00 & $3,00^{\mathrm{ab}}$ & 4,00 \\
$\mathrm{p}_{2} \mathrm{~d}_{2}$ & 2,00 & $2,33^{\mathrm{b}}$ & 3,00 \\
$\mathrm{p}_{2} \mathrm{~d}_{3}$ & 2,33 & $2,67^{\mathrm{ab}}$ & 3,67 \\
$\mathrm{p}_{3} \mathrm{~d}_{0}$ & 1,67 & $2,00^{\mathrm{c}}$ & 3,00 \\
$\mathrm{p}_{3} \mathrm{~d}_{1}$ & 2,00 & $2,00^{\mathrm{c}}$ & 2,67 \\
$\mathrm{p}_{3} \mathrm{~d}_{2}$ & 2,00 & $4,00^{\mathrm{a}}$ & 3,33 \\
$\mathrm{p}_{3} \mathrm{~d}_{3}$ & 2,33 & $2,67^{\mathrm{ab}}$ & 3,33 \\
\hline
\end{tabular}

Keterangan : Angka-angka yang diikuti huruf yang sama menunjukkan tidak berbeda nyata berdasarkan uji BNT pada taraf $\alpha=5 \%$

Hasil sidik ragam menunjukkan bahwa interaksi antara pupuk phosphor dan dolomit memberikan pengaruh tidak nyata terhadap parameter rata-rata pertambahantinggi tanaman, pertambahan jumlah daun umur 30 dan 90 hst, pertambahan diameter batang dan panjang pelepah daun namun memberikan respon yang nyata terhadap rata-rata pertambahan jumlah daun umur 60 hst pada perlakuan $\mathrm{p}_{3} \mathrm{~d}_{2}(2,5 \mathrm{~g}$ SP36/polybag dan $15 \mathrm{~g}$ dolomit/polybag). Hal ini didduga karena kandungan unsur hara $\mathrm{N}, \mathrm{P}$ dan $\mathrm{K}$ yang dibutuhkan oleh bibit kelapa sawit tersedia dalam jumlah yang cukup.Pada dosis tersebut kandungan unsur hara sesuai bagi bibit kelapa sawit terutama unsur nitrogen yang berperan

\section{KESIMPULAN}

1. Perlakuan pupuk phosphor memberikan pengaruh yang nyata dan sangat nyata terhadap rata-rata pertambahan jumlah daun umur 90 hari setelah tanam danpertambahan diameter batang umur 60 hari setelah tanam. Perlakuan terbaik ditunjukkan pada pupuk phosphor dengan dosis2,5 g/polybag $\left(\mathrm{p}_{3}\right)$.

2. Pelakuan dolomit memberikan pengaruh yang nyata dan sangat nyata terhadap rata-rata

\section{DAFTAR PUSTAKA}

Agoes, 1994. Aneka Jenis Media Tanam dan Penggunaanya. Penebar Swadaya, Jakarta.

Dinas Perkebunan Kalimantan Timur. 2009. Perkembangan perkebunan kelapa sawit. dalam

http://www.poskotakaltim.com/berita/read/696

9-areal-sawit-kaltim-capai-530.555-ha.html dalam pembentukan bagian vegetatif tanaman (daun). Keadaantersebut sesuai dengan pendapat Suriatna (1998), yang mengatakan bahwa apabila semua unsur yang dibutuhkan tanaman, terutama unsur nitrogen, fosfor dan kalium cukup tersedia di dalam tanah sesuai dengan kebutuhan tanaman, maka pertumbuhan tanaman dapat berjalan lancar dan normal.

Lebih lanjut dikemukakan oleh Maspary (2010), yang menyatakan bahwa jika unsur hara yang diberikan pada tanaman berada dalam kisaran yang sedikit atau sangat berlebihan maka unsur hara tersebut akan menghambat laju pertumbuhan tanaman tersebut.

pertambahan diameter batang umur 30 dan 60 hari setelah tanam. Perlakuan terbaik ditunjukkan pada pemberian dolomit dengan dosis $15 \mathrm{~g} /$ polybag $\left(\mathrm{d}_{2}\right)$.

3. Perlakuan interaksi antara pupuk phosphor dan dolomite memberikan pengaruh yang nyata terhadap rata-rata pertambahan jumlah daun umur 60 hari setelah tanam. Perlakuan terbaik ditunjukkan pada pemberian pupuk phosphor 2,5 g/polybag dan dolomit dengan dosis $15 \mathrm{~g} /$ polybag $\left(\mathrm{p}_{3} \mathrm{~d}_{2}\right)$.

Dwijoseputro. D, 1990. Pengantar Fisiologi Tumbuhan. Gramedia, Jakarta.

Gomez. KA and Arturo A Gomez. A, 1995. Prosedur Statistik Untuk Penelitian Pertanian. Terjamahan Syamsudin E dan Baharsjah JS.UI Press, Jakarta. 
Fauzi, YE Widyastuti, I Satyawibawa, R Hartono, 2004. Kelapa Sawit. Budidaya, Pemanfaatan Hasil dan Limbah, Analisis Usaha dan Pemasaran. Penebar Swadaya, Jakarta.

Hakim N, M.Y. Nyakpa, A.M. Lubis, S.G. Nugroho, M.R.Saul, M.A.Diha, G.B.Hong, H.H.Baoley, 1986. Dasar-dasar Ilmu Tanah, Unila, Lampung.

Hanafiah K.A, 2003. Rancangan Percobaan, Teori dan Aplikasi. Raja Grafindo, Jakarta.

Harjadi.SS, 1993. Pengantar Agronomi. Gramedia, Jakarta.

IPB, 2001. Pedoman Penulisan dan Penyajian Karya Ilmiah. IPB Press, Bogor.

Islami T dan Utomo WH, 1995. Hubungan Tanah, Air dan Tanaman. IKIP Press, Semarang.

Lingga, P dan Marsono, 2004. Petunjuk Penggunaan Pupuk. Penebar Swadaya, Jakarta.

Maspary. 2010. Fungsi unsur hara dalam proses pertumbuhan dan perkembangan tanaman. dalam http://www.gerbangpertanian.com/2010/04/fun gsi-unsur-hara-bagi-pertumbuhan-dan.html

Medbun, 2002. Renstra Disbun Kaltim dengan Visi Baru Media Perkebunan Edisi Oktober Nopember, Jakarta.

Novizan, 2003. Petunjuk Pemupukan yang Efektif. Agro Media Pustaka, Jakarta

Rinsema, 1993. Pupuk dan Pemupukan. Bharata Media, Jakarta.

Rismunandar, 2003. Tanah Seluk Beluknya Bagi Pertanian, Sinar Baru, Algesindo, Bandung.

Risza, 1994.Kelapa Sawit, usaha peningkatan produktivitas.Kanisius, Yogyakarta.

Sarief, E.S, 1986. Kesuburan dan Pemupukan Tanah Pertanian. Pustaka Buana, Bandung.

Sastrosayono S, 2005. Budidaya Kelapa Sawit, Agromedia Pustaka, Purwekerto.

Sawiji dan S. Wahana, 1987. Pemanfaatan Sumber Daya Alam Sebagai Media Tanam, Skripsi Sarjana Pada Fakultas Pertanian, Jember.
Suriatna, S. 1998. Pupuk dan cara pemupukan. Melton Putra, Jakarta.

Sutanto R, 2005. Dasar-Dasar Ilmu Tanah. Kanisius, Yogyakarta

Sutedjo MM, 1997. Pupuk dan Cara Pemupukan. Rineka Cipta, Jakarta.

Suyatno Risza, 1995. Upaya Peningkatan Produktivitas. Kanisius. Yogyakarta. 